\title{
All Progressives Congress (APC) N-power Programmes and Unemployed Nigerians in Nigeria
}

\author{
Ogbette, Afamefuna Samuel ${ }^{1}$, Bernard-Oyoyo Chimere ${ }^{2} \&$ Okoh, Joel Ogechukwu ${ }^{1}$ \\ 1. Department of Public Administration and Local Government, University of Nigeria, Nsukka, Enugu State \\ 2. Department of Political Science, Abia State University, Uturu
}

\begin{abstract}
This study examined the N-Power programmes and Unemployed Nigerians under the All Progressives Congress (APC) led federal government. The year 2016, was the actual year the programme started in Nigeria to make an impact on the lives of unemployed ones. The N-Power programmes are into three parts: N-Power Volunteer Corps (N-teach), N-Power Knowledge and N-Power Build. From our study, the programme has immensely gotten some numbers of unemployed Nigerians more engaged, more productive and more resourceful on duty. Looking at the Nigerian bureau of statistics 2018 data showed a $23.1 \%$ increase in unemployment for the third quarter of 2018 which brought the whole figure of the unemployed in the country to over 21 million Nigerians. In addressing this problem, the federal government in their own wisdom initiated N-Power as one of the social intervention programmes in the country. In addition to that, we suggest to the federal government to ensure that curriculum in schools are restructured in a way that two years are used in entrepreneurial studies in a four years duration course in the university and by so doing students shall not have the mindset of looking for job after school but rather having the mindset of creating jobs for themselves and others. And the federal government need to ensure that students are taught how to solve "social problems" not just to pass exams and come out with good grades! The very rich ones in the world are so rich because of knowledge economy and innovations.
\end{abstract}

Keywords: N-Power, programme, Unemployed, and Nigerians

DOI: $10.7176 / \mathrm{JRDM} / 54-08$

Publication date: April $30^{\text {th }} 2019$

\section{Introduction}

The number of unemployed Nigerians rose by 3.3 million to 20.9 million in the third quarter of 2018 (Q3' 18), a report from the National Bureau of Statistics (NBS) has shown. The NBS in its Labour Force Statistics - volume 1: Unemployment and underemployment report for Q3' 18, indicated that year-on-year (YoY) the rate of unemployment rose by 3.3 million or 19 percent to 20.9 million in Q3' 18 from 17.6 million in Q3' 17, while on quarterly basis, it rose by three percent from 20.3 million in Q2' 18 . The report showed that unemployed and under-employed female population far outpaced that of the men folk. Expectedly, the rate of job losses in the rural areas also far outpaced that of the urban centers with the rate of unemployment in the rural center increasing by 7.5 percent, while there was a 2.2 percent decrease in unemployment in the urban center respectively. The report stated: "The unemployment rate accordingly, increased from 18.8 percent in Q3 ' 17 to 23.1 percent in Q3' 18. The total number of people classified as unemployed, which means they did nothing at all or worked too few hours (under 20 hours a week) to be classified as employed increased from 17.6 million in Q4 2017 to 20.9 million in Q3 2018. "Of the 20.9 million persons classified as unemployed as at Q3 ' $18,11.1$ million did some form of work but for too few hours a week (under 20 hours) to be officially classified as employed, while 9.7 million did absolutely nothing. "Of the 9.7 million unemployed that did absolutely nothing as at Q3 2018, 90.1 percent of them or 8.77 million were reported to be unemployed and doing nothing because they were first time job seekers and have never worked before (Nnorom \& Adegbesan, 2018).

"On the other hand, 0.9 percent of the 9.7 million that were unemployed and doing nothing at all reported they were unemployed and did nothing at all because they were previously employed but lost their jobs at some point in the past which is why they were unemployed. "Total combined unemployment and underemployment rates increased from 40.0 percent in Q3 2017 to 43.3 percent in Q3, 2018”. According to the bureau, "Unemployment rate in Nigeria has been on the increase since the economic crisis in 2014. The unemployment rate based on NBS' $\mathrm{s}$ revised methodology were calculated to be 23.1 percent in the third quarter of 2018. Underemployment, however, has been gradually declining over the past four quarters, with then rate in Q3 was reported as 20.1 percent. It stated: " The increasing unemployment and declining underemployment rates imply that the fragile economic recovery is beginning to create employment. However, 
hours worked within these jobs are not yet enough for full time employment (40+ hours within the week). While this is on-going, the inflow of entrants into the labour market continues to grow steadily, minimizing the effect of any jobs created within the economy on the overall unemployment rate” (Nnorom \& Adegbesan, 2018).

However, the coming of All Progressive Congress party into Nigerian political space has positively touched few numbers of unemployed Nigerians by engagement in skill acquisition programme. All Progressives Congress (APC) is a political party formed on 6 February 2013 which took over the federal government of Nigeria from the People's Democratic Party (PDP) through an election in the year 2015. According to Wikipedia, APC candidate Muhammadu Buhari won the presidential election by almost 2.6 million votes against the then incumbent President Goodluck Jonathan of People's Democratic Party. Immediately the APC government came on seat, in their own wisdom, N-Power was launched! This is a programme under the social investment programme for job creation and empowerment initiatives. It is a programme by the APC government at the centre to help reduce unemployment by helping them to create jobs and engaging them in activities while unemployed (Olawale, 2018).

Npower is also linked to the Federal Government's policies in the economic, employment and social development arenas. N-power addresses the challenge of youth unemployment by providing a structure for large scale and relevant work skills acquisition and development while linking its core and outcomes to fixing inadequate public services and stimulating the economy (Npower, n.d). It is also a platform for diversifying the economy. N-power is preparing young Nigerians for a knowledge economy where, equipped with world-class skills and certification, they become innovators and movers in the domestic and global markets. Nigeria will have a pool of software developers, hardware service professionals, animators, graphic artists, building services professionals, artisans and others. N-power also focuses on providing our non-graduates with relevant technical and business skills that enhance their work outlook and livelihood (Npower, n.d).

The goals of the N-power programmes are; to reduce the rate of unemployment in the country, to bring about a system that would facilitate transferability of employability, entrepreneurial and technical skills, to bring solutions to ailing public service and government diversification policy (Olawale, 2018). Thus, this paper examined the impact of Npower initiative (s) and unemployed Nigerians.

The N-Power programmes are into three parts: N-Power Volunteer Corps (N-teach), N-Power Knowledge and N-Power Build

\section{N-Power Volunteer Corps (N-teach Programme)}

The N-power Volunteer Corps is a post-tertiary engagement initiative for Nigerians between 18 and 35 . It is a paid volunteering programme of 2 year duration. The graduates will undertake their primary tasks in identified public services within their proximate communities. All N-power volunteers are entitled to computing devices that will contain information necessary for their specific engagement, as well as information for their continuous training and development. In 2016, the Federal Government engaged 200,000 N-Power Volunteers. In 2007, the Federal Government enlisted 300,000 more. N-Power volunteers will provide teaching, instructional, and advisory solutions in 4 key areas (www.npower.gov.ng).

\subsection{N-Power Volunteer Corps (Teach Programmes) 2.1.1 N-Power Agro}

N-Power Agro Volunteers will provide advisory services to farmers across the country. They will disseminate the knowledge that has been aggregated by the Federal Ministry of Agriculture and Rural Development in the area of extension services. They will also gather data of Nigeria's agriculture assets.

Selection preference: Bachelor's degree, HND or OND in Nutrition, Agricultural Sciences, Agricultural Economics, Agronomy, Animal Science, Crop Science, Food Science and Technology, and other agro related disciplines.

Duration: 2 years

Job: Ultimately, N-Power Agro members can aspire to a life-long career in agriculture and other allied fields. Possible destinations include:

- Agriculture Extension Services Consultant

- Seed fertilizer and other input aggregators

- Farm managers

- Public sector jobs in agriculture

- Farming co-operatives management 
- Agro-entrepreneurship (www.npower.gov.ng/n-agro.html)

\subsubsection{N-Power Health}

Through the N-Power Health programme, young graduates formed part of the 500,000 N-Power Volunteer Corps. N-Power Health Volunteers will help improve and promote preventive healthcare in their communities to vulnerable members of the society including pregnant women and children and to families and individuals.

Selection preference: Preference will be given to holders of Bachelors's degree, HND, OND, in health sciences such as Medicine, Microbiology, Nursing, Public Health, Botany, Midwifery, Psychology or other allied disciplines in the sciences.

Duration: 2 years

Job: Ultimately, N-Power Health Volunteers can aspire to a life-long career in public health and other allied fields. Possible destinations include:

- Health Education Specialist

- Health Promotion Coordinator

- Public Relations Manager

- Breastfeeding Support Coordinator

- Health Office Administrator

- Health Research Analyst

- Social Worker and Counselor

- Health Services Manager

- Health Department Administrator

- Government Policy Analyst

- Displaced Persons Coordinator

- HIV/AIDS Educator

- Project Manager in Public Health

- Field Investigator

- Research Analyst

- Community Health Worker (www.npower.gov.ng/n-health.html)

\subsubsection{N-Power Teach}

The N-Power Teach programme engaged qualified graduates to help improve basic education delivery in Nigeria. N-power Teach Volunteers will be deployed as teacher assistants in primary/secondary schools around Nigeria. They will not replace the current teachers, will work as support teachers across Nigeria, assisting with teaching, school management and other functions within the schools. Where possible, they will also assist in taking basic education to children in marginalized communities.

Selection preference: All post-tertiary graduates from all disciplines inclusive of OND and NCE qualifications. Duration: 2 years

$J o b$ : Ultimately, N-Power Teach volunteers can aspire to a life-long career in teaching or allied fields. Possible destinations include:

- Professional Teaching

- Researcher, Research Associate, Senior Research Analyst

- Education Consultant, Associate

- Strategy Consultant

- Education Services Manager

- Project Manager

- Project Supervisor

- Social Services Analyst (www.npower.gov.ng/n-tech.html)

\subsubsection{N-Power Tax}

The Federal Government seeks to encourage non-compliant and partially compliant taxpayers to come clean and declare and pay their appropriate tax due to the government. A minimum of 3,700 N-Power volunteers will be selected to work as community tax liaison officers to work in their state's tax authorities. The N-Power community tax liaison officers will have the following key responsibilities which will include answering online inquiries, customer management, creating awareness of tax compliance. 
Selection preference: Bachelor's degree of Higher National Diploma (HND) in Economics, Law, Finance, Psychology and other allied disciplines in the social sciences.

Essential: knowledge and experience:

- Good knowledge of Microsoft office tools

- Good written and spoken English

- Good phone etiquette

- Excellent analytical and diagnostic aptitude

- Desirable: knowledge of tax laws and administration in Nigeria

Duration: 2 years

Job: Ultimately, N-Power Tax volunteers can aspire to a life-long career in finance or allied fields. Possible destinations include:

- Tax Assessor/Collector

- Financial Analyst

- Tax Auditor

- Legal and Compliance Manager

- Accountant (www.npower.gov.ng/n-tax.html)

\subsection{N-Power Knowledge}

The N-Power Knowledge programme is the Federal Government's first step towards diversifying to a knowledge economy. This programme will work alongside the planned eight innovation hubs across the country to provide incubation and acceleration of the technology and creative industries. The programme is a "Training to jobs" Initiative, essentially ensuring that participants can get engaged in the marketplace in an outsourcing capacity, as freelancers, as employees and as entrepreneurs (www.npower.gov.ng/n-knowledge.html).

\subsection{N-Power Knowledge Programmes}

\subsubsection{N-Power Creative}

The N-Power Creative programme will train and develop 5,000 young creative talents. The strategy is to put our creative industry on the global rader as exporters of the world-class services and content. Training will last 3 months, made up of 1 month in-class and a 2-months hands-on group project, across selected Nigerian cities. The participants will be trained and certified in one of the following courses: Animation, Graphic Design, Postproduction, and/ Script Writing. At the end of the training, some participants will get local and international internship opportunities while others will be linked to job and market opportunities. In addition, all participants will receive computing devices that will ensure that they master their skills during and after the training.

Selection preference:

- Unemployed graduates or non-graduates

- Must be between 18-35 years old

- Basic illustration skills will be an advantage for animation and graphic arts

- For script writing, creative writing skills and analytical writing skills will be an advantage

- Problem solving skills

- Ability to undertake self-tutorship

- Detail-oriented

- Analytical

Duration: 3 months

Job: Building/ Construction Project Management, Animator, Script Writer, Illustrator, Graphics Designer, Sound Editor, Film Editor, Visual Effects Artist, Game design, Desktop Publishing, Digital Media Publishing and Educational/Training Content Production (www.npower.gov.ng/n-creative.html).

\subsubsection{N-Power Tech Hardware}

The N-Power Tech for device technicians program will train and facilitate tooling for at least 10,000 technicians to boost the device serving and manufacturing industry. The output of this program will serve as a critical catalyst for the expansion of local capacity to service and produce mobile phones, tablets, computers and other relevant devices to serve the local and international market. Participants will undergo a hands-on training experience wherein they will be exposed to practical processes and tools to assemble and repair devices of varying specifications. At the end of the program, participants will be armed with the requisite technical skill to service devices in their local communities as well as work in a device assembly plant. The program will take 3 
months of training and 1 month of assessment, graduation and setup. Participants will be advised on opportunities to acquire tools to practice (www.npower.gov.ng/n-tech-hardware.html).

Selection preference: Unemployed graduates or non-graduates, must be between 18-35 years old, problem solving skills, and ability to undertake self-tutorship.

Duration: 3 Months

Job: Assembly Plant Technician, Trainer, Device network technician, Device maintenance, and Device technician.

\subsubsection{N-Power Tech Software}

The N-Power Tech for developers programme will train, tool and position 10,000 hands-on software developers for the local and international software development market. Participants will undergo a project based model to training wherein they will be exposed to foundational software development tools as well as resources to thrive as a modern day software developer entrepreneur. The programme will seek to establish the foundation knowledge, tools and platform upon which participants can pursue a career as software development entrepreneurs. Training will last 11 weeks and culminate with job fairs to link participants with placement opportunities within their respective localities. The programme will also offer a continuity platform to support participants with learning and engagement opportunities on a continuous basis. Participants will be enabled with a device to continue the practice and exploration of opportunities after training (www.npower.gov.ng/n-techsoftware.html).

Selection preference:

- Unemployed graduates or non-graduates

- Must be between 18-35 years old

- Problem solving skills

- Ability to undertake self-tutorship

- Detail-oriented

- Analytical

Duration: 3 Months Training

Job: App Developer, Game Developer, Web Developer, Computer System Analyst, Systems Software Developer, Software Tester, and Trainer

\section{N-Power Build}

N-Power Build is an accelerated training and certification (skills to job) programme that will engage and train 75,000 young unemployed Nigerians in order to build a new crop of skilled and highly competent workforce of technicians, artisans and service professionals. The focus industries include:

- Building Services

- Construction

- Built Environment Services

- Utilities

- Automotive

- Aluminum and Gas

Selection preference: Currently Unemployed, No degree or diploma, Aged between 18-35, Interest in fixing, Building and creating things.

Duration: 3 Months

Job: N-Power Build members can aspire to a career in construction, works and housing. Possible destinations include:

- Building/Construction Project Management

- Furniture Making and Design

- Electrical Maintenance and Repairs Services

- Plumbing

- Welding (www.npower.gov.ng/n-build.html)

\section{Assessment of Npower Initiative and its positive impact}

The Social Investment Programme (SIP), which was part of the campaign promises of the ruling All Progressives Congress (APC), has four components. These are the Home Grown School Feeding Programme for public primary schools; the Conditional Cash Transfer to less-privileged; N-Power for unemployed graduates; 
and the Government Enterprises Entrepreneurship Programme (GEEP) to encourage market women, artisans, traders, and others. Under the N-Power which is the flagship component of SIP, unemployed graduates of tertiary institutions are engaged in critical sectors like education, agriculture and health. Of all the SIP components and sub-components, the N-Teach is the most popular, due to the large number of youth deployed to teach in public schools (Haruna, 2018).

According to james Atoke, the Vice Principal of Christ School, Ado-Ekiti, a pre-colonial secondary school credited with educating most of the elite of Ekiti, including the current state governor, Ayo Fayose, NPower teachers have not only proven themselves as good teachers, but have also become indispensable assets. The 34 years veteran teachers even take up management roles in schools in remote communities due to the dearth of qualified or inadequate manpower within the education sector of the state.

School administrators in Kano State also expressed the same view on the services being provided by the N-Power teachers. Haliru Inuwa, the Principal of Government Secondary School, Daurawa said the eight Npower teachers deployed to his school since December 2016 have been the saving grace for him and his students. To our surprise, and gainst the earlier concern raised that they might not perform well in teaching, the N-power volunteer teachers are not only committed to their teaching, but are also punctual.

At the Maryam Alloma Mukhtar Government Girls Secondary School (MAMGGSS), kano, the management said they had nothing other than appreciation to the N-Power teachers. We are immensely happy with the N-Power programme because the volunteers have been contributing their quota towards the education of our students here in MAMGGSS, kano said Mustafa Adam, a senior teacher.

In Enugu State, according to Mr. Innocent Eze, the principal of Community High School, Obimo, Nsukka, applauded the federal government for the initiative. He went further to say that N-Power volunteer teachers has done well in his school and other schools around and at time pleading with the federal government to permanent their job for good of schools.

N-Power has turned around the lives of thousands of youth in this country and my advice is that it should not just stop here. Stopping it might not only mean depriving the people engaged in the scheme means sustenance, but it also means taking the services they are proving away. For example, here in Christ School, Ado-Ekiti, there is an Information and Communication Technology (ICT) laboratory that is fully equipped but not functional because there was no teacher to take the subject. But it has been my colleague and I handling the class since we came in December, 2016. That means once we are through with this progrramme now, it might mean they don't have ICT teachers again, because you are not sure of the discipline of the next batch that will be deployed. Same goes for Muhammed Ndaliman, a 32 years old graduate of Biology in Niger State, who said he was jobless until N-Power in 2016. Olakekan Femi who teaches Mathematics and Physics in Christ School AdoEkiti, said he was unemployed after he graduated in 2010. N-Power gave him his first job. Things were rough and life was practically difficult for me as a young graduate. But that is in the past now. With the N30,000 stipend I get monthly, I have been able to save some money to start up some petty business which is equally helping me to take care of myself and aged parents (Haruna, 2018).

On state economies, the Director-General of N-Power in Niger State, Muhammed Usman, said aside the social engagement of youth, the APC government of President Buhari has also used its SIP to boost the economy of states across Nigeria. He said about 5,110 youth were engaged in Niger State and posted across the state. And for 24 months these people are going to be paid N30, 000 each, which means about N3.7 billion injected into the Niger state economy. He went further to say with another batch of 8,000 persons expected to be engaged, Niger state stands to have a total of N5.7 billion injected into its economy by the Buhari administration and same goes to other states where billions are injected monthly as a result of SIP.

\section{Recommendations and Conclusion}

From the study, the federal government N-Power programmes has done massively well in ensuring that reasonable number of unemployed Nigerians are engaged fruitfully. This is a welcome development but there is need for the federal government to increase the number being taken on yearly basis by cutting cost of governance and at the same time ensure that senior N-Power sets are given exist package after their duration. By so doing, they will be able to stand on their own without necessarily looking for white collar job by implementing skills learnt in the course of the programme. Again, we observed that the N-Power volunteers have been more productive, more engaged and more resourceful as a result this wonderful initiative. Though, it is a scheme but we suggest to the government to ensure something of this nature is enshrined into the constitution for good of the unemployed Nigerians and by looking at the Nigerian bureau of statistics 2018 data showed a $23.1 \%$ increase in unemployment for the third quarter of 2018 brought the whole figure of the unemployed in the country to over 21 million Nigeria. This clearly explains why government recruitment usually receives embarrassingly high applicants.

Again, the federal government should ensure that curriculum in schools are restructured in a way that two years are used in entrepreneurial studies in a four years duration course in the university and by so doing 
students shall not have the mindset of looking for job after school but rather having the mindset of creating jobs for themselves and others. And the federal government need to ensure that students are taught how to solve "social problems" not just to pass exams and come out with good grades! The very rich ones in the world are so rich because of knowledge economy and innovations.

\section{References}

All Progressives $\quad$ Congress (n.d) In $\quad$ Wikipedia. $\quad$ Available athttps://en.m.wikipedia.org/wiki/All Progressives Congress Accessed Date: 16-1-2019

Haruna, A. (2018). Special report: how buhari's N-power programme is transforming lives, improving education. Premium times. Available at https://www. Premiumtimesng .com /news/headlines/273735-special-report- how-buharis--n-power-programme-is-transforming-livesimproving-education.html Accessed Date: 24-1- 2019

Nnorom, N. \& Adegbesan, E. (December 20, 2018). Unemployed Nigerians increase by $3.3 \mathrm{~m}$ to $20.9 \mathrm{~m}-$ NBS. Vanguard (Online). Retrieved on 19th April, 2019 from https://www.vanguardngr.com/2018/12/unemployed-nigerians-increase-by-3-3m-to-20-9m-nbs/

Npower (n.d). About us. Retrieved from www.npower.gov.ng/about-us.html Accessed Date: 18-1-2019

Npower (n.d). Npower Agro. Retrieved from www.npower.gov.ng/n-agro.html Accessed Date: 18-1-2019

Npower (n.d). Npower build. Retrieved from www.npower.gov.ng/n-build.html. Accessed Date: 19-1-2019

Npower (n.d). Npower creative. Retrieved from www.npower.gov.ng/n-creative.html. Accessed Date: 19-1-2019

Npower (n.d). Npower Health. Retrieved from www.npower.gov.ng/n-health.html. Accessed Date 18-1-2019

Npower (n.d). Npower knowledge. Retrieved from www.npower.gov.ng/n-knowledge.html Accessed Date 19-12019

Npower (n.d). Npower Tax. Retrieved from: www.npower.gov.ng/n-tax.html. Accessed Date: 18-1-2019

Npower (n.d). Npower tech hardware. Retrieved from www.npower.gov.ng/n-tech-hardware.html. Accessed Date: 19-1-2019

Npower (n.d). Npower tech software. Retrieved from www.npower.gov.ng/n-tech-software.html. Accessed Date 19-1-2019

Npower (n.d). Npower tech. Retrieved from www.npower.gov.ng/n-tech.html. Accessed Date 18-1-2019

Npower (n.d). N-Power Volunteer Corps (Teach Programme). Retrieved from www.npower.gov.ng Accessed Date: 18-1-2019

Olawale, S. (2018). What is N-power, all you need to know about Npower.gov.ng. Naijaquest.com. Retrieved from https://naijaquest.com/what-is-n-power-all-you-need-to-know-about-npower-gov-ng Accessed Date: $18-1-\quad 2019$ 